\title{
Desertifilum fontinale sp. nov. (Oscillatoriales, Cyanobacteria) from a warm spring in East Africa, based on conventional and molecular studies
}

\author{
Pawan K. DadheECh ${ }^{1,2}$, Huda Mahmoud ${ }^{3}$, Kiplagat Kotut ${ }^{4} \&$ Lothar Krienitz $^{1, *}$
}

\author{
${ }^{1}$ Leibniz-Institute of Freshwater Ecology and Inland Fisheries, Alte Fischerhütte 2, D-16775 Stechlin, \\ Germany; *Corresponding author e-mail: krie@igb-berlin.de \\ ${ }^{2}$ Central University of Rajasthan, Department of Microbiology, Bandarsindri 305801, Kishangargh (Rajasthan), \\ India \\ ${ }^{3}$ Kuwait University, Department of Biological Sciences, P.O. Box: 5969 Safat-13060, Kuwait \\ ${ }^{4}$ Embu University College, P.O. Box 6-60100 Embu, Kenya
}

\begin{abstract}
Desertifilum is a filamentous cyanobacterium of crusts and biofilms, recently described from the extreme hot and dry Thar Desert in north-western India. A new species was isolated from a warm spring near Lake Bogoria, Kenya and was characterised by light and electron microscopy and phylogenetically using the 16S rRNA gene, beta and alpha subunits including intergenic spacer ( $c p c$ BA-IGS) and 16S-23S internal transcribed spacer (ITS). The aquatic habitat of the new material from Kenya revealed a wider distribution of members of this genus. The new taxon was found to be closest to Desertifilum tharense (Oscillatoriales). The separation of the new species described here as D. fontinale sp. nov., using conventional and molecular traits, was based on differences in phenotypic features, 16S-23S ITS sequence and habitat.
\end{abstract}

Key words: Desertifilum; Oscillatoriales; Cyanobacteria; Molecular phylogeny; 16S rRNA; ITS; Lake Bogoria; Warm springs

\section{INTRODUCTION}

Cyanobacteria are capable of colonising nearly all habitats on our planet (WhitTon \& PotTs 2000; VINCENT 2009). Although most of the taxa that have so far been described are found in water, some species have successfully invaded terrestrial environments and are able to survive with a minimum of water supply. Even desert soils have been found to be suitable for cyanobacterial settlements. Recently, a new taxon of the order Oscillatoriales was described from the extremely hot and dry Thar Desert in north-western India: Desertifilum tharense DADHEECH et KRIENITZ (DADHEECH et al. 2012a). This cyanobacterium grows in biological crusts of dry sand dunes and in moist surface films on stones in areas with a mean annual precipitation of 250 $\mathrm{mm}$. The tiny filaments have a diameter of 2.0-3.7 $\mu \mathrm{m}$ and possess a colourless sheath. Interestingly, the cells contained gas vacuoles, suggesting that the taxon thrived in the aquatic environment in primeval times. In this study, we describe a new species of the genus Desertifilum from a warm spring in East Africa. The occurrence of this species raises new questions on the distribution of members of this genus. Lake Bogoria National Reserve is a Ramsar Site located in an arid to semi-arid climatic area with various water habitats including lakes and springs (Mugo 2007). Lake
Bogoria, which is located in the centre of the reserve, is a saline alkaline lake that hosts hundreds of thousands of Lesser Flamingos (Brown 1973; HARPer et al. 2003). Numerous hot springs and some geysers located near the shore or under the lake surface are active as a result of the volcanic origin of this area (CIONI 1992; OwEN et al. 2004; McCALL 2010). In addition to the alkaline hot springs, there are also a number of warm springs that receive ground water or water of low salinity. The low salinity water discharge is an important water source for the livestock of the local pastoralists (OwEN et al. 2004). The focus of this study is a member of the cyanobacterial flora of a warm spring located directly on the shoreline of the Lake Bogoria, Kenya. Based on a polyphasic taxonomic appro-ach that combined both morphological and molecular analyses, this study describes a new species of cyanobacteria.

\section{Materials ANd Methods}

Sampling and culturing . The cyanobacterium described in this study was collected from a small warm spring on the shoreline of Lake Bogoria in the Lake Bogoria National Reserve on 9 November 2011. The sampling site is situated at an altitude of $998 \mathrm{~m}$ above sea level at the following coordinates: $0^{\circ} 18^{\prime} 23^{\prime \prime} \mathrm{N}, 36^{\circ} 04^{\prime} 43^{\prime \prime} \mathrm{E}$. The spring discharges 
its water directly into Lake Bogoria through a small rivulet that was $3 \mathrm{~m}$ long. The physico-chemical properties of the spring water were as follows: temperature $37{ }^{\circ} \mathrm{C}, \mathrm{pH}$ 7.86 , conductivity $1.02 \mathrm{mS.m}{ }^{-1}$, salinity of $0.3 \mathrm{ppt}$. The spring serves as a source of water for livestock watering by pastoralists that graze their livestock within the reserve (Fig. 1a). At the time of sampling, the physico-chemical properties of the waters of Lake Bogoria near the mouth of the spring differed considerably from those of the spring water and were as follows: temperature $29^{\circ} \mathrm{C}, \mathrm{pH} 10.49$, conductivity 43.90 $\mathrm{mS} . \mathrm{m}^{-1}$, and salinity $28.4 \mathrm{ppt}$. Hence the low discharge from the spring investigated did not have a significant impact on the physico-chemical properties of the lake.

The cyanobacteria in the warm spring occurred in mat form with a "frog-skin-like appearance (Fig. 1b). Samples collected from these cyanobacterial mats were divided into three sub-samples, i) air dried materials, ii) fixed samples (formaldehyde, final concentration 2.5\%), and iii) fresh samples stored in the water of the sampling site.

Single filaments were isolated from fresh samples using a micropipette and transferred into $15 \mathrm{ml}$ culture tubes for establishment of clonal cultures. The strain KR 2012/2, which is the subject of this investigation, was maintained in suspension using a modified BOURRELLY medium at the algal culture collection of the Leibniz-Institute of Freshwater Ecology and Inland Fisheries (KRIENITZ \& WIRTH 2006). The strain was grown at room temperature under a $14 \mathrm{~h}$ : $10 \mathrm{~h}$ lightdark regime. A sample of the culture strain was deposited in the culture collection of the UTEX under the designation UTEX number LB 2975 (The Culture Collection of Algae at The University of Texas at Austin, USA). An air-dried as well as a formaldehyde-fixed culture sample was deposited at the Botanical Museum at Berlin-Dahlem, Germany, under the designation B 400040927.

Light, scanning and transmission electron microscopy. The cyanobacterium was studied under a Nikon Eclipse E600 light microscope (LM) with differential interference contrast (Nikon Corporation, Japan). Microphotographs (Fig. 2) were taken with a Nikon digital camera DS-Fi1 and Nikon software NIS-Elements D.

Cyanobacterial samples for scanning electron microscopy (SEM) studies were fixed with 3\% glutaraldehyde in cacodylate buffer ( $\mathrm{pH} 7.4$ ) for 24 hours. The specimen were then washed thrice with the same buffer after which the samples were post-fixed with $2 \%$ osmium tetroxide in cacodylate buffer ( $\mathrm{pH}$ 7.4) for 2 hours. The samples were then washed thrice with cacodylate buffer to remove all traces of osmium tetroxide before being dehydrated in a graded ethanol series (i.e. in progressively higher concentrations of ethanol, starting with $30 \%$ and ending with $100 \%$ ethanol). The dehydration step was performed at room temperature inside a fume cupboard on a slow-speed rotator (INFILTissue Rotator, USA) using a critical point dryer (BalTEC, CPD 030, Australia). Samples were then mounted on aluminum stubs where they were coated with light gold for 2 min in a Sputter Coater (BAL-TEC, SCD050, Australia) after which they were examined using a Leo Supra $50 \mathrm{VP}$ 50 Variable Pressure Field Emission Scanning Microscope with a infra red CCD Camera (Zeiss, Germany). The images were analyzed using SAM Graphical user interface software (Atmel Corp., USA).

Cyanobacterial samples for Transmission Electron microscopy (TEM) studies were fixed with $3 \%$ glutaraldehyde in cacodylate buffer ( $\mathrm{pH}$ 7.4). The specimens were then post fixed with $2 \%$ osmium tetroxide in cacodylate buffer ( $\mathrm{pH}$ 7.4). Enough osmium tetroxide was added to cover the samples and kept for 2 hours on a rotator. The specimens were then washed thrice using new buffer for each wash so as to remove all traces of osmium tetroxide. The clean specimens were dehydrated in progressively higher concentrations of ethanol. The dehydration steps were carried out in a Leica Automatic Processor (ReicheartLynx, Australia). The samples were then pervaded with epoxy resin. The specimens were trimmed with glass knife and cut into ultra thin sections $(90 \mathrm{~nm})$ with a diamond knife using an ultra microtome (Leica Ultracut UCT, Austria) after which they were transferred onto 150 mesh copper grids where they were stained with $2 \%$ uranyl acetate and lead citrate using an ultra stainer (LEICA, Australia). The specimens were finally investigated under the transmission electron microscope JEOL JEM-1200EX II (JEOL, Japan). Micrographs were taken using a digital camera (Gatan CCD camera, USA).

Genomic DNA extraction, PCR amplification and sequencing. The genomic DNA from fresh culture of the strains KR 2012/2 and PD2001/17 (Desertifilim tharense) was extracted using Dynabeads DNA DIRECT System I (Invitrogen/Dynal Biotech, Norway) following the steps outlined in the manufacturer's manual. PCR of 16S rRNA gene, 16S-23S internal transcribed spacer (ITS) and beta and alpha subunits including intergenic spacer ( $c p c$ BA-IGS) of phycocyanin operon was performed in a Peltier Thermal Cycler PTC 200 (MJ Research Inc., USA) using the Taq PCR Mastermix Kit (Qiagen). The amount of template DNA was adjusted when necessary to generate sufficient PCR products for DNA sequencing. The forward primers $\mathrm{pA}$ and reverse primer B23S (cyanobacterial specific) were used for the amplification of 16S rRNA gene of the strain KR2012/2 (EDWARDS et al. 1989; GKELIs et al. 2005) with an annealing temperature of $50{ }^{\circ} \mathrm{C}$ for the PCR protocol (BALlot et al. 2008). The PCR protocol, primers 322 and 340 (ITEMAN et al. 2000) were used for amplification ITS region. The primers PCßf and PCar (NEILAN et al. 1995) were employed to obtain a partial sequence of $c p c \mathrm{BA}-\mathrm{IGS}$ locus. The PCR protocol for the amplification of phycocyanin operon of the strains KR2012/2 and PD 2001/17 was used as described by BALLOT et al. (2008). Amplified products were purified using Qiaquick PCR purification columns (Qiagen) according to manufacturer's protocol.

The purified PCR product of 16S rRNA gene was sequenced using the primers $\mathrm{pA}, \mathrm{pC}, \mathrm{pE}, \mathrm{pDr}, \mathrm{pFr}$ and $\mathrm{pHr}$ (EDWARDS et al. 1989). The ITS and $c p c$ BA-IGS region was sequenced using the same primers as in the PCR product above with an ABI 3100 Avant Genetic Analyzer using BigDye Terminator v3.1 Cycle Sequencing Kit (Applied Biosystems, Applera, Germany) as described in the manufacturer's manual.

The genetic potential of the strains (KR2012/2 and PD2001/17) to produce a variety of toxins was assessed using different primer sets and PCR cycling protocols as previously described: HEPF/HEPR for $m c y \mathrm{E}$ (JuNGBLUT \& NeILAn 2006), FAA/RAA for $m c y B$ (NeIlan et al. 1999), AnaC-genF/AnacC-genR for anacystin (RANTALA-YlineN et al. 2011) and sxtA-F/sxtA-R for saxitoxin (AL-TEBRINEH et al. 2010). The nucleotide sequences reported in this study have been deposited in the NCBI database under the GenBank accession numbers KJ028038 (16S rRNA gene), KJ028039 (ITS) and KJ028040-KJ028041 (cpcBA-IGS). 
Phylogenetic analyses. The cyanobacterial sequences of 16S rRNA gene were retrieved from nucleotide database of NCBI and aligned using software MUSCLE (EDGAR 2004). The alignment was checked visually using the manual sequence alignment editor align v05/2008 (Hepperle 2008). Sequence similarity (identity matrix) of the closest sequences was cal-culated from all positions of the alignment including gaps using the program Align. The closest relatives to our sequences were detected using BLASTN (www. ncbi.nlm.nih.gov/blast). In carrying out the phylogenetic analyses, we initially selected a large group of sequences (>1100 bp) belonging to non-heterocytous taxa to examine the phylogenetic position of our strain. Later we selected a smaller subset based on the relatedness of the sequences while excluding taxa of uncertain affiliation. For a synoptic view of the phylogenetic tree, only sequences from the Oscillatoriales were chosen. A maximum-likelihood (ML) approach was used to investigate evolutionary relationships between taxa of Oscillatoriales and the novel strain using the program RAxML ver. 7.0.0 (STAMATAKIS 2006), implemented in raxmlGUI (Silvestro \& MichalaK 2011). The selection of the best fit model for a phylogenetic analysis was determined by jModelTest 2 tool (DARRIBA et al. 2012) using nucleotide evolution method (GTR + Gamma + Invariant

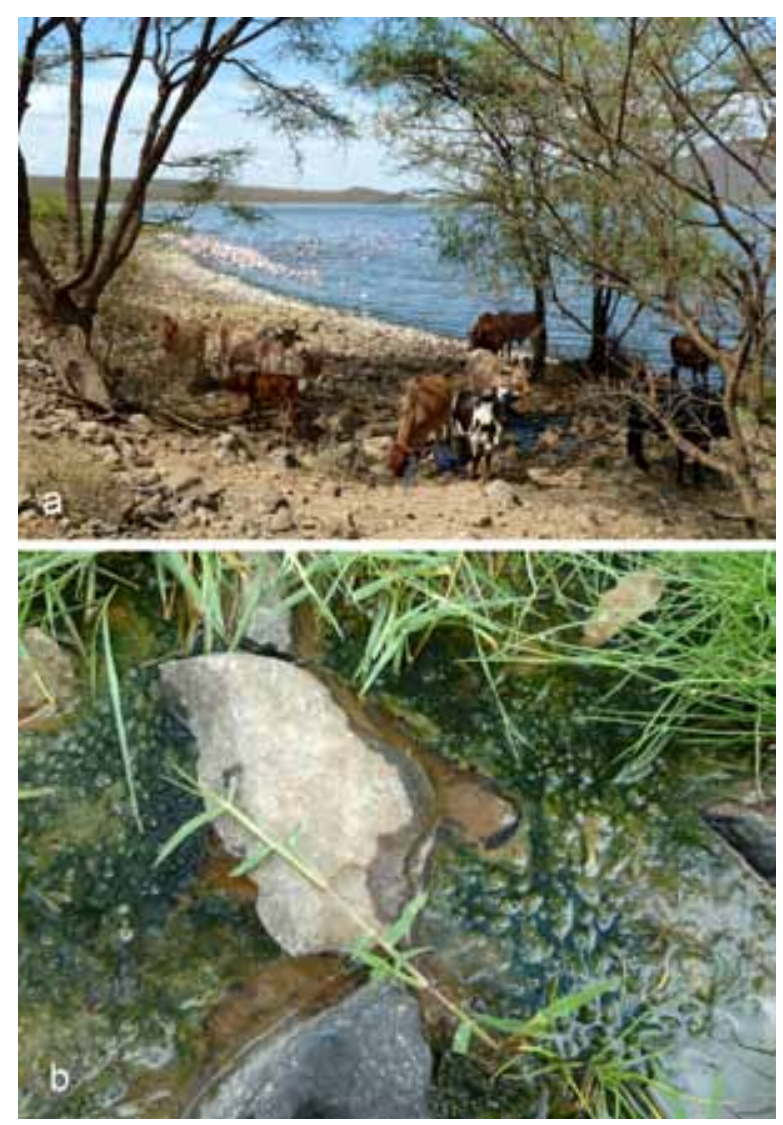

Fig. 1. Sampling site of Desertifilum fontinale: (a) The warm spring with a herd of cattle visiting it for watering (foreground). The shoreline of the saline-alkaline Lake Bogoria is only few metres away. The lake hosts large numbers of Lesser and Greater Flamingos, as seen in the background. The spring is located in a semi-arid environment; the floor is of volcanic origin and covered by lava rocks; (b) Cyanobacterial mats with $D$. fontinale forming a frog-skin-like appearance on the warm spring.
Sites) based on the Akaike Information Criterion (PosADA \& BuCKLEY 2004). This mutation model was implemented in the maximum-likelihood analysis in RAxML, which utilized the thorough bootstrap approach with 1000 bootstrap replicates. The resulting tree was visualized using TreeView v1.6.6. Maximum parsimony and neighbor joining trees were also constructed using MEGA 5 (TAMURA et al. 2011) and compared to the topologies of the trees obtained to establish and validate the phylogenetic position of the strain studied (data not shown). Gloeobacter violaceus PCC 7421 (AF132790) was chosen as the outgroup taxon.

The pattern of ITS sequences and their various regions were determined with the reference sequences (ITEMAN et al. 2000; Boyer et al. 2001). Secondary structures of the 16S-23S rRNA ITS regions were determined using RNA Mfold version 3.5 (ZUKER 2003) with default settings. The overview graphics of the secondary structures of ITS regions were performed in Pseudo Viewer version 2.5 (BYuN \& HAN 2003).

\section{ReSUlts}

\section{Phenotypic and ultrastructural characterization}

The cyanobacterial strain described in this paper as a new species of the genus Desertifilum was found growing as free floating mats in a warm spring near Lake Bogoria, Kenya. The variable width of the filaments ranging from 4 to $7 \mu \mathrm{m}$ (Fig. 2) was evident under the LM. Its filaments were straight or slightly wavy. At the crosswall of cells, no or slight constrictions were visible. The trichomes were enclosed by a firm hyaline sheath, forming filaments that exhibited gliding or oscillating movements. The development of necridic cells was observed (Fig. 2a). Extrusions were common at the apices of a few cells (Fig. 2 b, c). All morphological observations were based on cultured material.

Under the SEM, the non-heterocytous filaments were cylindrical, straight or slightly bent (Fig. 3a). Trichomes were uniseriate, unbranched and made up of cylindrical cells that were generally shorter than broad. However, cells found closer to the filament tip were generally longer. Apical cells were attenuated, conical shaped with rounded apexes. However, some trichomes had apical cells that were rounded to varying degrees (Fig. 3b-d).

TEM micrographs showed that the trichomes were covered by a persistent fibrous, multilayered sheath, which was separated from the cell membrane by a transparent zone (Fig. $4 \mathrm{a}-\mathrm{c}$ ). Thylakoids were parietally arranged in the peripheral zone inside the cells in a condensed form that made it difficult to determine the number of thylakoids. Polyhedral bodies (carboxysomes), polyphosphate bodies and lipid inclusions occurred in all cells either in the cytoplasm or near the cell wall. Gas vacuoles were not observed. 

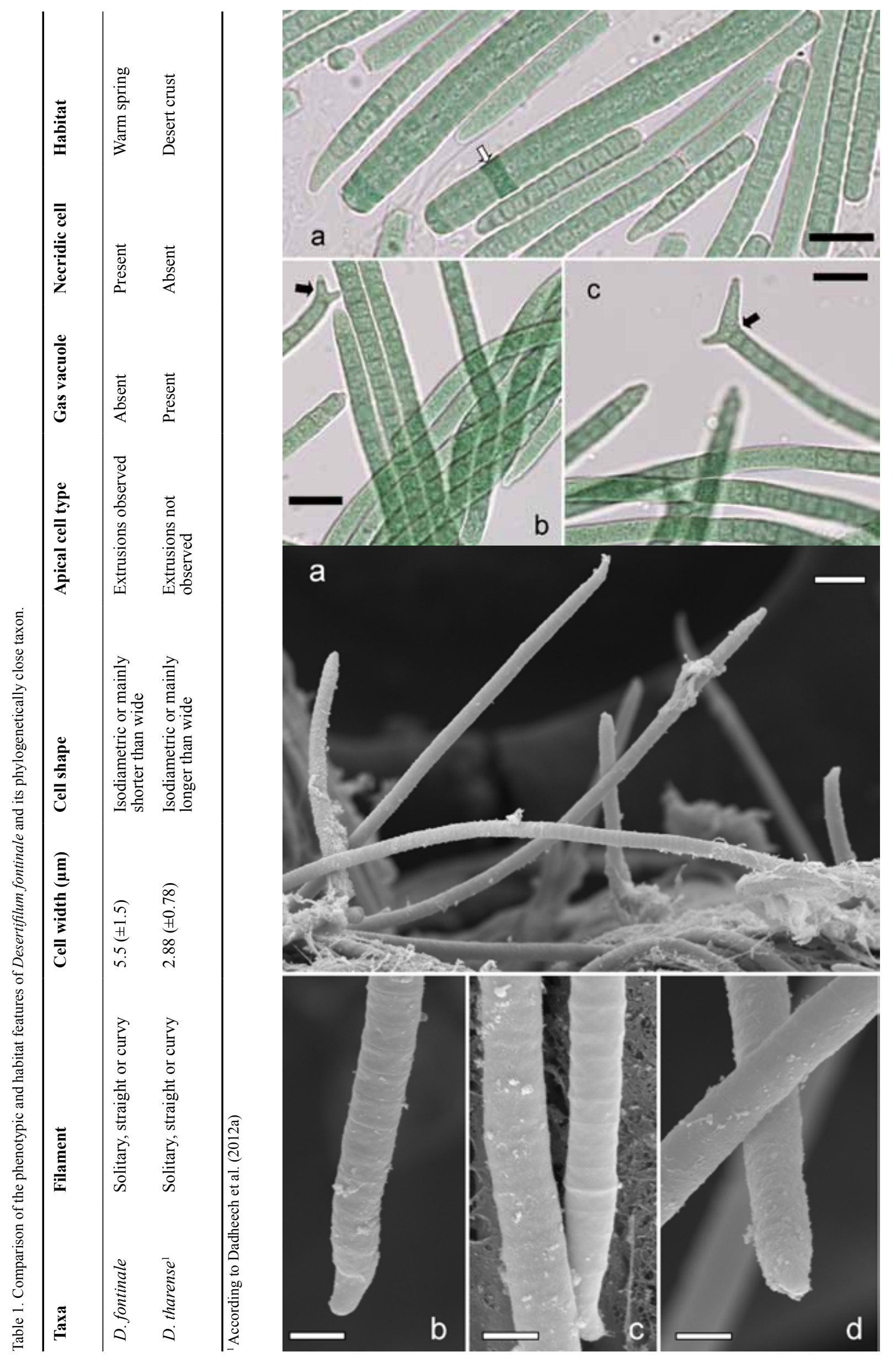


\section{Molecular studies}

A partial 16S rRNA gene sequence (1285 bp) was obtained and compared with closely related taxa retrieved from GenBank database. The BLASTN analysis revealed that the novel strain showed $99 \%$ similarity in 16S rRNA gene sequence with all four strains of Desertifilum tharense. A ML tree constructed with 67 sequences of $16 \mathrm{~S}$ rRNA gene belonging to oscillatorian taxa showed that $D$. fontinale sequence is positioned in a well defined sub-clade that is mainly composed of strains of $D$. tharense (Fig. 6).

A sequence of $551 \mathrm{bp}$ of ITS region was obtained by PCR amplification of 16S-23S ITS region. In the BLASTN analysis, the maximum identity of ITS sequence of $D$. fontinale and sequences available in GenBank was $95 \%$, which corresponded to strains of D. tharense (accession no. FJ158998-FJ159001). The ITS region of the novel strain and D. tharense comprised of both $\mathrm{tRNA}^{\mathrm{Ile}}$ and tRNA ${ }^{\text {Ala }}$ genes and other conserved and variable regions (data not shown). We drew the secondary structures of D1-D1', Box B, V2 and $\mathrm{V} 3$ regions of the strain KR2012/2 and D. tharense (PD2001/17). The secondary structure of D1-D1', V2 and V3 helices of the novel strain and $D$. tharense are presented in this paper because other ITS region (Box B helix) exhibit similar secondary structures in both taxa (data not shown). The D1-D1'helix of D. fontinale possessed 57 nucleotides (nt) while $D$. tharense had $56 \mathrm{nt}$. In both species, the secondary structure of D1-D1' region has three loops and a unidirectional bulge. Differences were observed in basal loop, main stem and terminal loop of D1-D1' helices (Figs. 7a, b). Moreover, significant differences between the V2 helices secondary structure of $D$. fontinale and $D$. tharense were observed (Figs. 7c, d). The V2 region helices of the novel strain and $D$. tharense consisted of $74 \mathrm{nt}$ and $64 \mathrm{nt}$ respectively. The differences in V3 helices of both species were also observed in total number of nucleotides, number of nucleotides in terminal loop and terminal stalk (Figs 7 e, f).

Comparing the two Desertifilum species, $D$. fontinale and D. tharense (PD2001/17), using cpcBAIGS sequencing, which investigates the full portion of the intergenic spacer and a partial sequence of beta and alpha sub unit of the phycocyanin locus, revealed $98.8 \%$ similarity of the nucleotides (531 nt) of both species.

Fig. 2. Micrographs of Desertifilum fontinale under the LM: (a) Filaments of different width and different apical cells types; the white arrow indicates a necridic cell; (b, c) Straight and wavy filaments, some apical regions with extrusions. The black arrows indicate the extrusions in apical cells. Scale bars $10 \mu \mathrm{m}$.

Fig. 3. SEM micrographs of Desertifilum fontinale: (a) An overview on the thallus; $(b-d)$ the apical region of different filaments. Scale bars (a) $10 \mu \mathrm{m}$, (b-d) $5 \mu \mathrm{m}$.
To determine the genetic potential of the novel isolate and $D$. tharense for the production of cyanotoxins, PCR analyses were performed using several specific primer pairs. None of the genetic loci responsible for production of cyanotoxins such as microcystin, anatoxin-a and saxitoxin were amplified in the two taxa.

\section{Description of the novel species}

\section{Desertifilum fontinale DADHEECH, МАHMOUD, KotUT et KriEnitz sp. nov.}

Diagnosis: Filaments blue green, $5.5( \pm 1.5) \mu \mathrm{m}$ wide, solitary or entangled with varying filament lengths, unconstricted or slightly constricted at cross-walls, motile (gliding and oscillation), with a thin colourless sheath, attenuated at the ends, sometimes with extrusions at the apices. Cells isodiametric, shorter than long. Gas vacuoles absent. Propagation by binary fission or necridic cells.

Based on 16S rRNA gene sequence data, most similar to Desertifilum tharense DADHEECH et KRIENITZ, but differing in cell size, shape of apical cell, ecology and sequences of ITS region and phycocyanin locus.

Holotype (designated here): a dried sample of the strain KR 2012/2 (B 40 0040927) deposited in the Herbarium at the Botanical Museum at Berlin, Dahlem, Germany. Type strain: a living strain deposited at UTEX (The Culture Collection of Algae at the University of Texas at Austin) under the temporary no.UTEX LB 2975

Type locality: warm spring, Lake Bogoria National Reserve, Kenya.

Etymology: the specific epithet (Latin: fons = spring, water) refers to the habitat at the locus classicus.

Icona typica: a drawing of Desertifilum fontinale, strain KR 2012/2 (Fig. 5).

\section{Discussion}

Warm springs are known to host many species of Oscillatoriales (GEITLER 1930-1932; ANAGNOSTIDIS \& ZeHNDer 1964; KomÁreK \& ANAgnostidis 2005). However, the novel species of Desertifilum described here is the first member of this genus to be reported from an aquatic habitat. Until now, the genus Desertifilum has been characterised by only the type species $D$. tharense, which occurs in biological desert crusts in the Thar Desert of India (DADHEECH et al. 2012a). The new species differs from $D$. tharense in terms of habitat, morphology (Table 1) and molecular characteristics.

The polyphasic approach is considered to be the most appropriate way to characterize cyanobacterial taxa (Comte et al. 2007; Sciuto et al. 2011). Several new genera belonging to the order Oscillatoriales have been described in the last decade (ABED et al. 2002; Rasoulouniriana et al. 2009; TAton et al. 

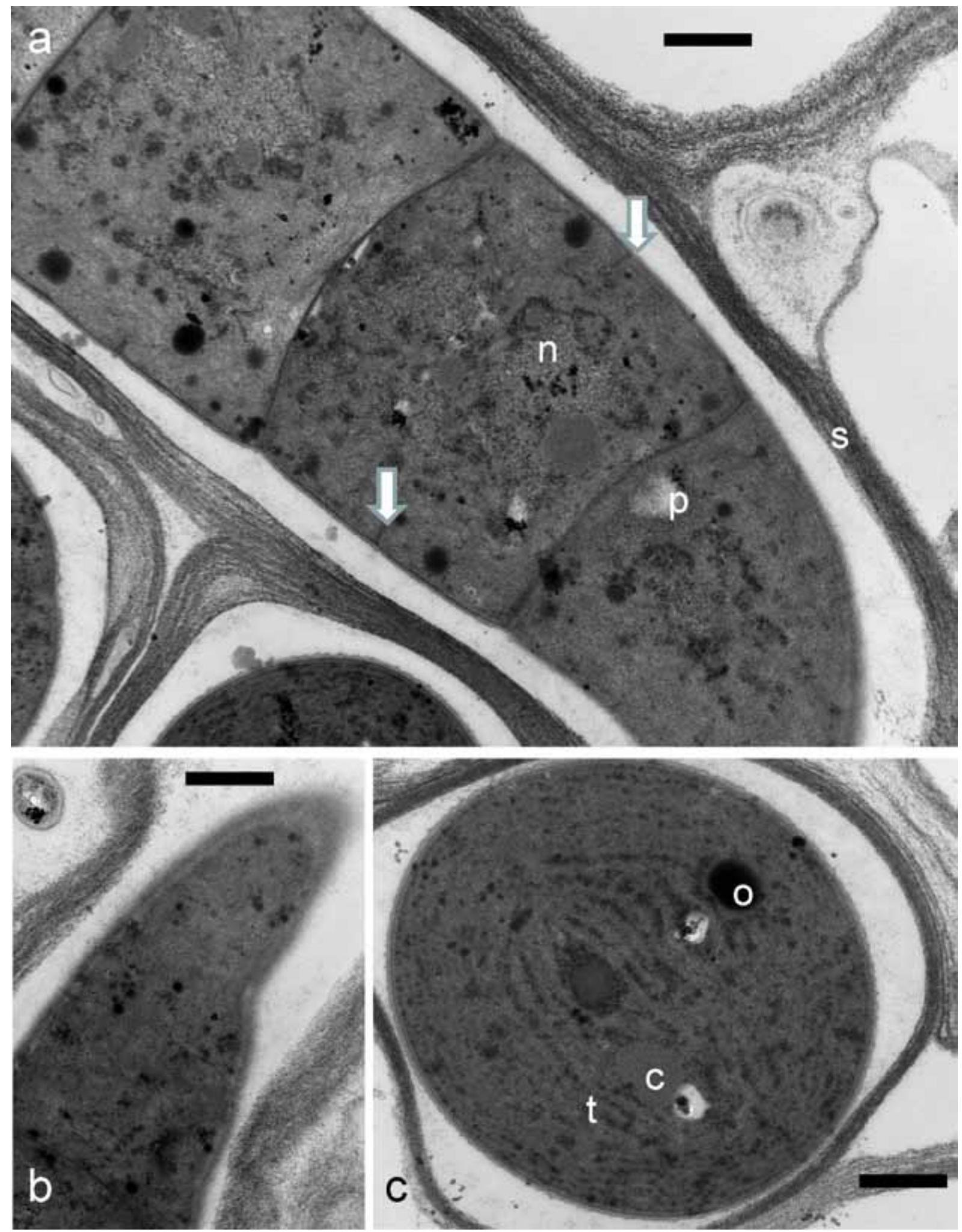

Fig. 4. TEM micrographs of Desertifilum fontinale: $(\mathrm{a}, \mathrm{b})$ longitudinal section; white arrows indicate beginning of binary fission; (c) cross sectional view. Scale bars $1 \mu \mathrm{m}$. Abbreviations: (c) carboxysome, (n) nucleoid, (o) oil droplet, (p) polyphosphate body, (s) sheath, (t) thylakoid. 

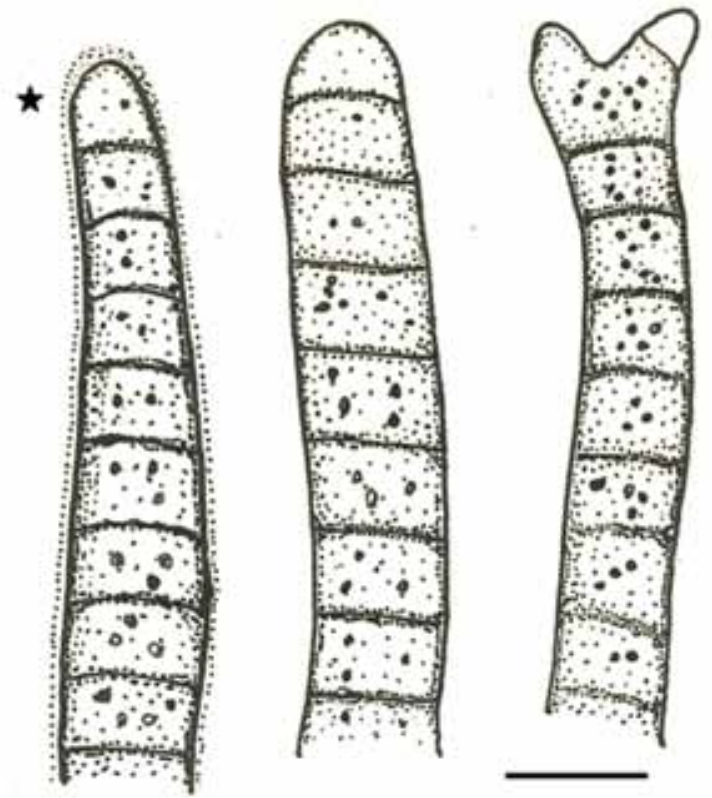

Fig. 5. Drawing of Deserifilum fontinale, strain KR 2012/2. The icona typica is indicated by an asterisk. Scale bar $5 \mu \mathrm{m}$.

2011; CASAmatta et al. 2012; DAdHeEch et al. 2012a, b; Thu et al. 2012; Zammit et al. 2012; NGUYen et al. 2013) and many others have been revised (SuDA et al. 2002; SiEgesmund et al. 2008; Turicchia et al. 2008; StrunECKÝ et al. 2011; ChATChAWAN et al. 2012; STRUNECKÝ et al. 2013) using this approach. Fox et al. (1992) demonstrated that 16S rRNA gene similarity data are not sufficient to provide a clear-cut identity of a prokaryote species. It has been suggested that a single species of a cyanobacterium must have uniform genetic, ecological and morphological characteristics (KomÁreK \& MAREŠ 2012). The 16S rRNA gene sequence of our taxon shows $99 \%$ similarity to the type species of the genus Desertifilum and this confirms its close relationship to this genus. However, the sequence of this novel taxon emerges as a separate lineage from the sub-clade that includes four strains of Desertifilum tharense (Fig. 6). This lineage is supported by $100 \%$ bootstrap value.

In addition to $16 \mathrm{~S}$ rRNA gene phylogenetic analysis, we also compared the ITS region and the cpcBA-IGS locus sequences of the two species of Desertifilum. Despite the high similarity ( $>98 \%)$ of the cpcBA-IGS locus, some considerable difference (5\%) in the ITS region was noted. Secondary structures of different helices (D1-D1', Box-B, and V3) of the ITS have been used to differentiate cyanobacterial taxa particularly of the order Oscillatoriales (SIEGESMUND et al. 2008; BoHUnicKÁ et al. 2011; JoHANSEN et al. 2011; Perkerson et al. 2011; DAdheEch et al. 2012b; HašLer et al. 2012). We found considerable differences in D1D1', V3 helices of D. fontinale and D. tharense. Strains of Coleofasciculus chthonoplastes were differentiated using secondary structure of V2 region of the ITS (SiEgesmund et al. 2008). In this study, we also analyzed the V2 region of the ITS to enable us discriminate our strain from $D$. tharense. A conspicuous heterogeneity was noted in secondary structures of $D$. fontinale and $D$. tharense. Our finding suggests that this region can be used widely as a taxonomic marker along with other regions so as to achieve a better resolution when characterizing cyanobacterial taxa. The high percent dissimilarity in ITS sequence and a clear distinction in secondary structure of various ITS regions from those of $D$. tharense support the recognition of the novel strain as a separate species of the genus Desertifilum.

PCR-based molecular detection of potential cyanotoxins production by cyanobacteria has been being successfully employed as a tool for characterizing oscillatorian taxa (DADHEECH et al. 2012b, 2013; LOPES et al. 2012). In our investigations, we used selective primers to test for the presence of genes known for the synthesis of cyanotoxins (microcystin, anatoxin-a and saxitoxin). However, none of these genes was detected in both $D$. fontinale and $D$. tharense.

Although $D$. fontinale exhibits a close phylogenetic (16S rRNA gene) relationship to $D$. tharense, the two species have considerable morphological differences in cell size, cell shape and nature of the apical cell. A few new species of oscillatorian genera have been created those sharing $>99 \%$ sequence similarity of $16 \mathrm{~S}$ rRNA gene but differed in morphology and ecological preferences (CASAmatta et al. 2005; BoHUNiKÁ et al. 2011).

Recently, a new species of Phormidium ( $P$. etoshii) has been described that had high similarity in sequence of $16 \mathrm{~S}$ rRNA gene but differed in morphological and ecological features from known Phormidium species (DADHEECH et al. 2013a). The trichome of the novel taxon is broader than that of $D$. tharense. The average cell breadth for $D$. fontinale is 5.5 $( \pm 1.5) \mu \mathrm{m}$ while the maximum cell breadth measured in D. tharense is $3.7 \mu \mathrm{m}$ (DADHEECH et al. 2012a). Cell shape in $D$. fontinale ranges from isodiametric to wider than long, while in $D$. tharense, it ranges from isodiametric to longer than wide. Although both taxa have elongated round apical cells, protrusions can develop only in the apices of $D$. fontinale. These protrusions probably result from tensions and strengths in the filament that ruptures the sheath. They are comparable to false branching observed in several Oscillatoriales such as Schizothrix and Pseudophormidium when the trichome breaks down (ANAGNOSTIDIS \& KomÁreK 1988). Some similarity in ultrastructural features is evident in both $D$. fontinale and $D$. tharense. However, cells of the novel isolate lack gas vacuoles which are present in strains of $D$. tharense and considered as an autapomorphic character for description of the genus Desertifilum (DADHEECH et al. 2012a). The possession of aerotopes can be interpreted as relict from a period when the area of the Thar Desert was wet with several lakes and ponds fed by the ancient river Saraswati, some forty to fifty 


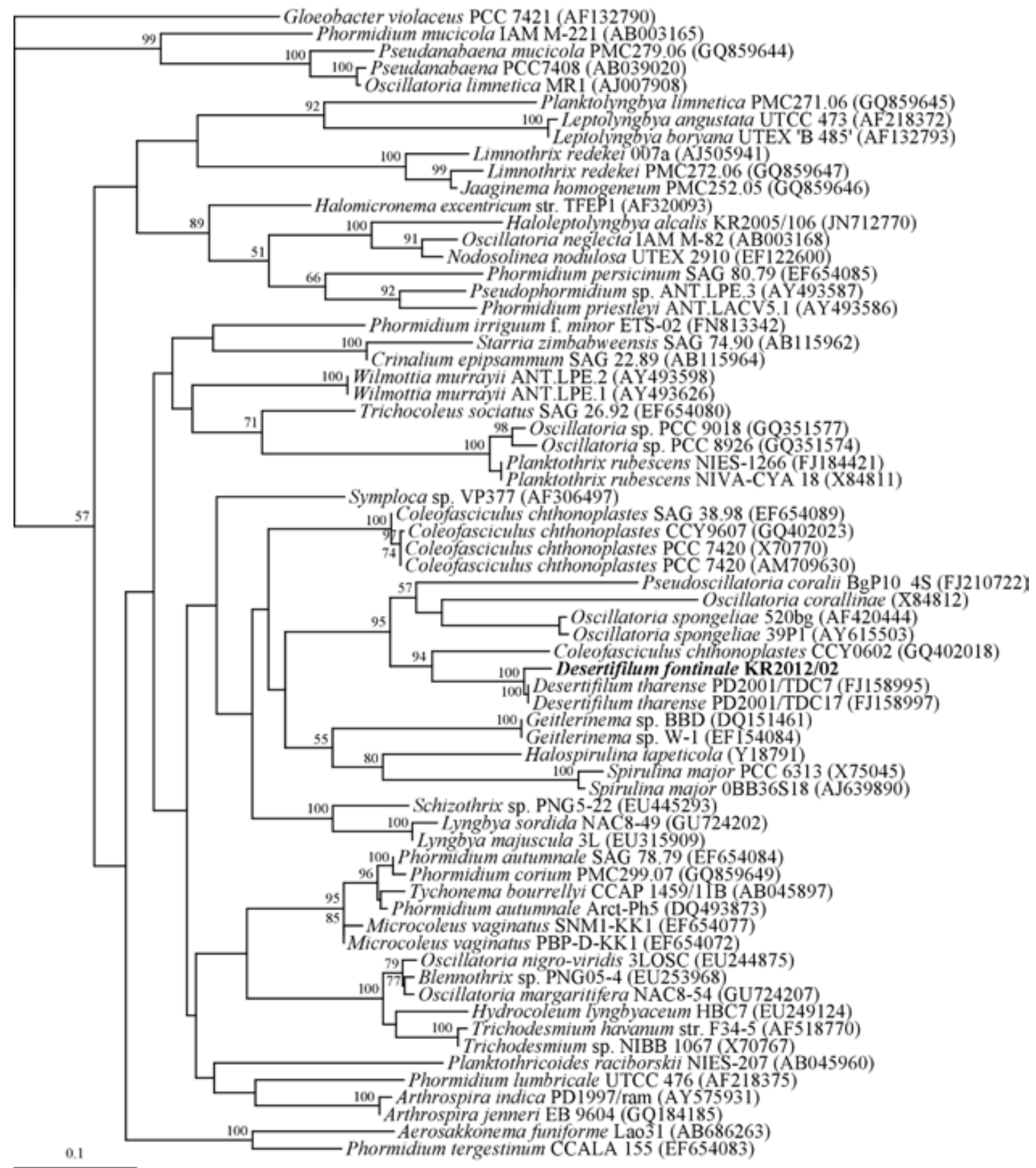

Fig. 6. Maximum likelihood phylogenetic tree based on 16S rRNA gene sequences. Numbers above branches indicate bootstrap support ( $>50$ $\%)$ from 1,000 replicates. The novel species is in bold font.

thousand years ago (SAini \& Mujtaba 2010; Mitra \& BHADU 2012). However, absence of aerotopes in $D$. fontinale does not conclusively suggest a more ancient character of this species as life in the water could be as a result of a secondary invasion of the aquatic habitat after a life on soils, under the harsh conditions of the volcanic Bogoria area. So far, D. fontinale has only been detected in warm springs, and not in the numerous hot springs found within the vicinity to the locus classicus. Interestingly, the cyanobacterial flora of these hot springs is quite different from that of the warm springs (HINDÁK 2001; KRIENITZ et al. 2003; DADHEECH et al. 2013b). Based on our observations, it is clear that mandatory presence of gas vesicles in the cells for characterization of the genus Desertifilum needs revision. We suggest an emendation in the description of the genus Desertifilum to indicate that gas vacuoles may present or absent in the cells and increasing range of the trichome width. 

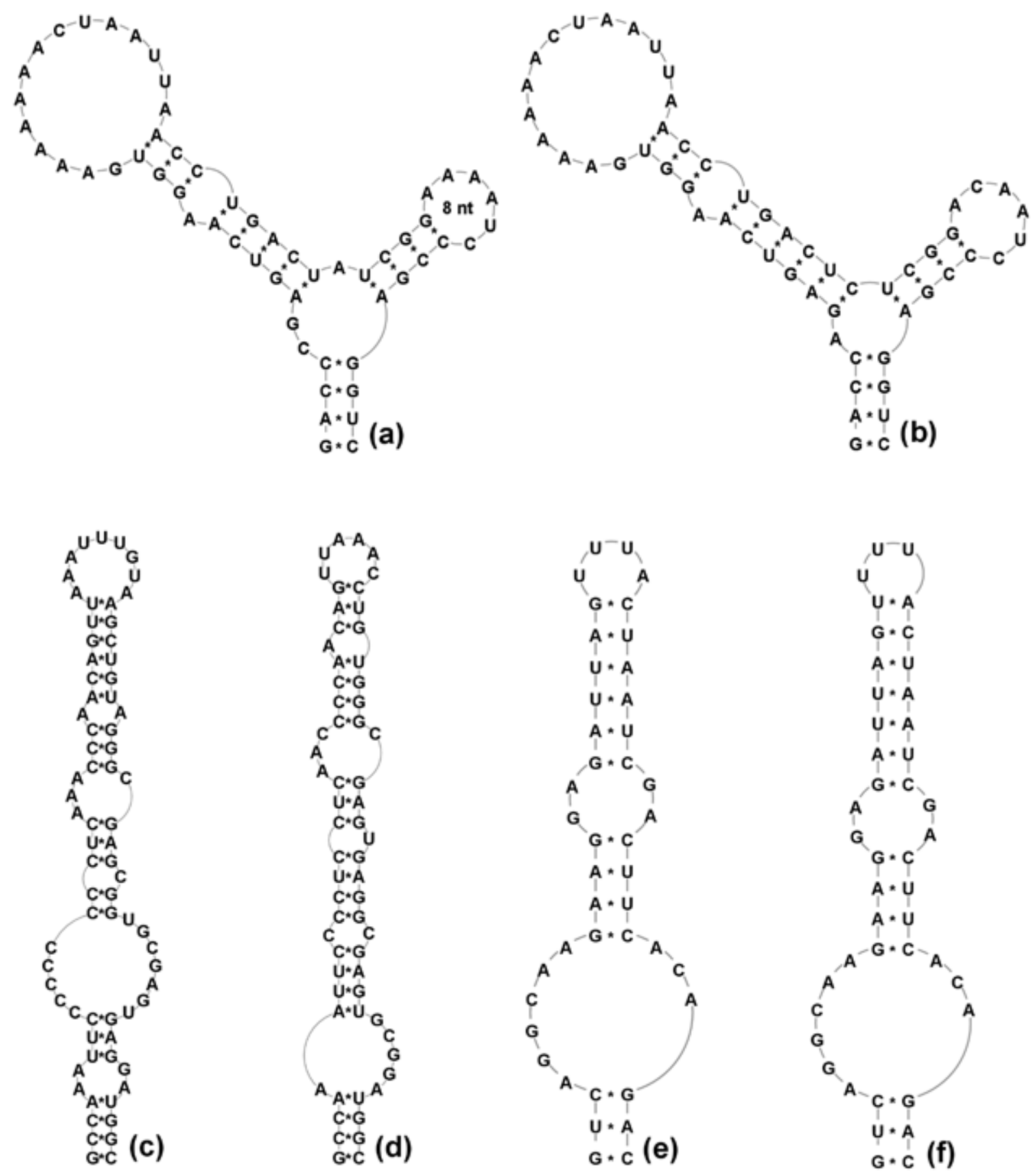

Fig. 7. 16S-23S ITS regions secondary structures of Desertifilum fontinale and Desertifilum tharense. (a) D1-D1' helix of D. fontinale; (b) D1D1' helix of $D$. tharense; (c) V2 helix of $D$. fontinale; (d) V2 helix of $D$. tharense; (e) V3 helix of $D$. fontinale; (f) V3 helix of $D$. tharense.

\section{Emendation of the genus Desertifilum DADHEECH et} KRIENITZ

Thallus thin, pale to bright blue green, filaments solitary or densely entangled, varying in length, filament motile through gliding and oscillation, sheath thin, colourless, attached to trichome (agglutinated), not constricted or slightly constricted at cross wall, trichome 2.0-7.0 $\mu \mathrm{m}$ wide, attenuated at the ends, cells cylindrical, isodiametric or up to $2 \times$ longer than wide, sometimes slightly barrel shaped, cell content homogenous, gas vacuole present or absent, apical cells long-conical and rounded apex, usually curved differentially. Reproduction by binary fission or formation of necridic cells. Moderately thermophilic, sensitive to high salinity. It differs from other genera of Oscillatoriales by the order of phenotypic features and substantial difference in the nucleotides sequence of 16S rRNA gene. 
ACKNOWLEDGEMENTS

We thank the Government of Kenya for giving permission to carry out this research (No. MOEST 13/001/31 C 90). Our sincere appreciation is also due to the County Councils of Koibatek and Baringo Districts for granting access to Lake Bogoria and for their collaboration. In particular, we thank William Kimosop, the Senior Warden of Lake Bogoria National Reserve for helpful assistance. We are thankful to Monika Degebrodt for her technical assistance with sequencing and Monika Papke for laboratory assistance. The authors extend their thanks to Ms. Ahlam Al-Kadi and Mr. Javed K. Surti from the Nanoscope Science Center, Kuwait University for their help with the scanning and transmission microscopy.

\section{REFERENCES}

Abed, R.M.M.; Garcia-Pichel, F. \& M. Hernandez-Marine, M. (2002): Polyphasic characterization of benthic, moderately halophilic, moderately thermophilic cyanobacteria with very thin trichomes and the proposal of Halomicronema excentricum gen. nov., sp. nov. - Arch. Microbiol. 177: 361-370.

Al-Tebrineh, J.; Mihali, T.K.; Pomati, F. \& Neilan, B.A. (2010): Detection of saxitoxin-producing cyanobacteria and Anabaena circinalis in environmental water blooms by quantitative PCR. Appl. Environ. Microbiol. 76: 7836-7842.

Anagnostidis, K. \& KomáreK, J. (1988): Modern approach to the classification system of cyanophytes. 3 Oscillatoriales. - Arch. Hydrobiol., Suppl. 80, 1-4 (Algological Studies 50-53): 327-472.

Anagnostidis, K. \& Zehnder, A. (1964): Beitrag zur Kenntnis der Blaualgenvegetation der Thermen von Baden und Leukerbad (Schweiz). - Schweiz. Z. Hydrol. 26: 170-176.

Ballot, A.; Dadheech, P.K.; Haande, S. \& Krienitz, L. (2008): Morphological and phylogenetic analysis of Anabaenopsis abijatae and Anabaenopsis elenkinii (Nostocales, Cyanobacteria) from tropical inland water bodies. - Microb. Ecol. 55: 608-618.

BohunickÁ, M.; Johansen, J.R. \& FučíKovÁ, K. (2011): Tapinothrix clintonii sp. nov. (Pseudanabaenaceae, Cyanobacteria), a new species at the nexus of five genera. - Fottea 11: 127-140.

BOYer, S.L.; Flechtner, V.R. \& JoHAnSEn, J.R. (2001): Is the 16S-23S rRNA internal transcribed spacer region a good tool for use in molecular systematics and population genetics? A case study in cyanobacteria. - Mol. Biol. Evol. 18: 1057-1069.

Brown, L.H. (1973): The Mystery of the Flamingos. - East African Publishing House, Nairobi.

Byun, Y. \& Han, K. (2003): PseudoViewer2: visualization of RNA pseudoknots of any type. - Nucl. Acids Res. 31: 3432-3440.

Casamatta, D.A.; Johansen, J.R.; Vis, M.L. \& Broadwater, S.T. (2005): Molecular and morphological characterization of ten polar and near-polar strains within the Oscillatoriales (Cyanobacteria). - J. Phycol. 41: 421-438.

Casamatta, D.; Stanić, D.; Gantar, M. \& Richardson, L.L. (2012): Characterization of Roseofilum reptotaenium (Oscillatoriales, Cyanobacteria) gen. et sp. nov. isolated from Caribbean black band disease. Phycologia 51: 489-499.

Chatchawan, T.; Komárek, J.; Strunecký, O.; Šmarda, J. \&
Peerapornpisal, Y. (2012): Oxynema, a new genus separated from the genus Phormidium (Cyanophyta). - Cryptogamie, Algologie 33: 41-59.

Cioni, R.; Fanelli, G.; Guidi, M.; Kinyariro, J.K. \& Marini, L. (1992): Lake Bogoria hot-springs (Kenya) Geochemical features and geothermal implications. - J. Volcan. Geotherm. Res. 50: 231-246.

Comte, K.; Sabacka, M.; Carre-Mlouka, A.; Elster, J. \& KOMÁREK, J. (2007): Relationships between the Arctic and the Antarctic cyanobacteria; three Phormidiumlike strains evaluated by a polyphasic approach. FEMS Microbiol. Ecol. 59: 366-376.

DAdHeECh, P.K.; Abed, R.M.M.; Mahmoud, H.; Mohan, M.K. \& KRIENITZ, L. (2012a): Polyphasic characterization of cyanobacteria isolated from desert crusts, and the description of Desertifilum tharense gen. et sp. nov. (Oscillatoriales). - Phycologia 51: 260-270.

Dadheech, P.K.; Casamatta, D.; Casper, P. \& Krienitz, L. (2013a): Phormidium etoshii sp. nov. (Oscillatoriales, Cyanobacteria) described from the Etosha Pan, Namibia, based on morphological, molecular and ecological features. - Fottea 13: 235-244.

Dadheech, P.K.; Glöckner, G.; Casper, P.; Kotut, K.; Mazzoni, C.J.; Mbedi, S. \& Krienitz, L. (2013b): Cyanobacterial diversity in the hot spring, pelagic and benthic habitats of a tropical soda lake. - FEMS Microbiol. Ecol. 85: 389-401.

Dadheech, P.K.; Mahmoud, H.; Kotut, K. \& Krienitz, L. (2012b): Haloleptolyngbya alcalis gen. et sp. nov., a new filamentous cyanobacterium from the soda lake Nakuru, Kenya. - Hydrobiologia 691: 269-283.

Darriba, D.; Taboada, G.L.; Doallo, R. \& Posada, D. (2012): jModelTest 2: more models, new heuristics and parallel computing. - Nature Methods 9: 772.

EDGAR, R.C. (2004): MUSCLE: multiple sequence alignment with high accuracy and high throughput. - Nucl. Acids Res. 32: 1792e1797.

Edwards, U.; Rogall, T.; Blocker, H.; Emde, M. \& Bottger, E.C. (1989): Isolation and direct complete nucleotide determination of entire genes. Characterization of a gene coding for $16 \mathrm{~S}$ ribosomal RNA. - Nucl. Acids Res. 17: 7843-7853.

Fox, G.E.; Wisotzkey, J.D. \& JurTshuK, P. (1992): How close is close: $16 \mathrm{~S}$ rRNA sequence identity may not be sufficient to guarantee species identity. - J. Syst. Evol. Microbiol. 42: 166-170.

Geitler, L. (1932): Cyanophyceae von Europa. - In: RABENHORST, L. (ed.): Kryptogamenflora von Deutschland, Österreich und der Schweiz, Vol. 14 (Ed. by R. KolKwitz). - 1196 pp., Akademische Verlagsgesellschaft, Leipzig.

Gkelis, S.; Rajaniemi, P.; Vardaka, E.; Moustaka-Gouni, M.; Lanaras, T. \& Sivonen, K. (2005): Limnothrix redekei (Van Goor) Meffert (cyanobacteria) strains from Lake Kastoria, Greece form a separate phylogenetic group. - Microb. Ecol. 49: 176-182.

Harper, D. M.; Childress, R.B.; Harper, M.M.; Boar, R.R.; Hickley, P.H.; Mills, S.C.; Otieno, N.; Drane, T.; Vareschi, E.; Nasirwa, O.; Mwatha, W.E.; Darlington, J.P.E.C. \& Escuté-Gasulla, X. (2003): Aquatic biodiversity and saline lakes: Lake Bogoria National Reserve, Kenya. - Hydrobiologia 500: 259-276.

HaŠLer, P.; DVOŘÁK, P.; Johansen, J.R.; Kitner, M.; ONDŘEJ, V. \& PoulíčKovÁ, A. (2012): Morphological and 
molecular study of epipelic filamentous genera Phormidium, Microcoleus and Geitlerinema (Oscillatoriales, Cyanophyta/Cyanobacteria). Fottea 12: 341-356.

Hepperle, D. (2008): Align, multisequence alignment editor Ver. 05/2998 Sequentix - Digital DNA Processing. Klein Raden, Germany.

HindÁK, F. (2001): Thermal microorganisms from a hot spring on the coast of Lake Bogoria, Kenya. Nova Hedwigia, Beiheft 123 (Algae and extreme environments): 77-93.

Iteman, I.; RippKa, R.; TANDEAu de Marsac, N. \& Herdman, M. (2000): Comparison of conserved structural and regulatory domains within divergent $16 \mathrm{~S}$ rRNA-23S spacer sequences of cyanobacteria. - Microbiology 146: $1275-1286$.

Johansen, J.R.; KováČiK, L.; Casamatta, D.A.; FučíkovÁ, K. \& KAŠTOVSKÝ, J. (2011): Utility of 16S-23S ITS sequence and secondary structure for recognition of intrageneric and intergeneric limits within cyanobacterial taxa: Leptolyngbya corticola $\mathrm{sp}$. nov. (Pseudanabaenaceae, cyanobacteria). - Nova Hedwigia 92: 283-302.

Jungblut, A.D. \& Neilan, B.A. (2006): Molecular identification and evolution of the cyclic peptide hepatotoxins, microcystin and nodularin, synthetase genes in three orders of cyanobacteria. - Arch. Microbiol. 185: 107-114.

KomÁReK, J. \& Anagnostidis, K. (2005): Cyanoprokaryota, 2, Oscillatoriales. - In: BÜDEL, B.; GÄRTNER, G., Krienitz, L. \& Schagerl, M. (eds): Süsswasserflora von Mitteleuropa, Vol. 19/2. - 759 pp., Spectrum Academischer Verlag, Elsevier, München.

KomÁreK, J. \& Mareš, J. (2012): An update to modern taxonomy (2011) of freshwater planktic heterocytous cyanobacteria. - Hydrobiologia 698: 327-351.

KrienitZ, L. \& WiRTh, M. (2006): The high content of polyunsaturated fatty acids in Nannochloropsis limnetica (Eustigmatophyceae) and its implication for food web interactions, freshwater aquaculture and biotechnology. - Limnologica 36: 204-210.

Krienitz, L.; Ballot, A.; Kotut, K.; Wiegand, C.; Pütz, S.; Metcalf, J.S.; Codd, G.A. \& Pflugmacher, S. (2003): Contribution of hot spring cyanobacteria to the mysterious deaths of Lesser Flamingos at Lake Bogoria, Kenya. - FEMS Microbiol. Ecol. 43: 141148.

Lopes, V.R.; Ramos, V.; Martins, A.; Sousa, M.; Welker, M.; Antunes, A. \& Vasconcelos, V.M. (2012): Phylogenetic, chemical and morphological diversity of cyanobacteria from portuguese temperate estuaries. - Mar. Environ. Res. 73: 7-16.

McCAll, J. (2010): Lake Bogoria, Kenya: Hot and warm springs, geysers and Holocene stromatolites. Earth-Science Reviews 103: 71-79.

Mitra, D. S. \& Bhadu, B. (2012): Possible contribution of River Saraswati in groundwater aquifer system in western Rajasthan, India. - Curr. Sci. 102: 685-689.

Mugo, K. (ed) (2007): Lake Bogoria National Reserve, World Ramsar Site (No. 1057). Integrated Management Plan 2007-2012. - County Council of Baringo, County Council of Koibatek and WWF-EARPO: 1- 48.

Neilan, B.A.; Jacobs, D. \& Goodmann, A. (1995): Genetic diversity and phylogeny of toxic cyanobacteria determined by DNA polymorphisms within the pycocyanin locus. - Appl. Environ. Microbiol. 61: 3875-3883.

Neilan, B.A.; Dittmann, E.; Rouhiainen, L.; Bass, R.A.; Schaub, V.; Sivonen, K. \& Börner, T. (1999): Nonribosomal peptide synthesis and toxigenicity of cyanobacteria. - J. Bacteriol. 181: 4089-4097.

Nguyen, L.T.T.; Cronberg, G.; Moestrup, Ø. \& DaugbJerg, N. (2013): Annamia toxica gen. et sp. nov. (Cyanobacteria), a freshwater cyanobacterium from Vietnam that produces microcystins: ultrastructure, toxicity and molecular phylogenetics. - Phycologia 52: $25-36$.

Owen, R.B.; Renaut, R.W.; Hover, V.C.; Ashley, G.M. \& MuasYa, A.M. (2004): Swamps, springs and diatoms: wetlands of the semi-arid Bogoria-Baringo Rift, Kenya. - Hydrobiologia 518: 59-78.

Perkerson, R.B.; Johansen, J.R.; KováčiK, L.; Brand, J.; Kaštovský, J. \& CasamattA, D.A. (2011): A unique pseudanabaenalean (Cyanobacteria) genus Nodosilinea gen. nov. based on morphological and molecular data. - J. Phycol. 47: 1397-1412.

Posada, D. \& Buckley, T.R. (2004): Model selection and model averaging in phylogenetics: advantages of Akaike information criterion and Bayesian approaches over likelihood ratio tests. - Syst. Biol. 53: 793-808.

Rantala-Ylinen, A.; Kana, S.; Wang, H.; Rouhiainen, L.; Wahlsten, M.; Rizzi, E.; Berg, K.; Gugger, M. \& Sivonen, K. (2011): Anatoxin-a synthetase gene cluster of the cyanobacterium Anabaena sp. strain 37 and molecular methods to detect potential producers. - Appl. Environ. Microbiol. 77: 7271-7278.

Rasoulouniriana, D.; Siboni, N.; Ben-Dov, E.; KramarskyWinter, E.; Loya, Y. \& Kushmaro, A. (2009): Pseudoscillatoria coralii gen. nov., sp nov., a cyanobacterium associated with coral black band disease (BBD). - Diseases Aquat. Organisms 87: 91-96

SaINI, H. S. \& Mujtaba, S.A.I. (2010): Luminescence dating of the sediments from a buried channel loop in Fatehabad area, Haryana: insigt into vedic Saraswati river and its environment. - Geochronometria 37: $29-35$.

Sciuto, K.; Rascio, N.; Andreoli, C. \& Moro, I. (2011): Polyphasic characterization of ITD-01, a cyanobacterium isolated from the Ischia Thermal District (Naples, Italy). - Fottea 11: 31-39.

Siegesmund, M.A.; Johansen, J.R.; Karsten, U. \& Friedl, T. (2008): Coleofasciculus gen. nov. (cyanobacteria): Morphological and molecular criteria for revision of the genus Microcoleus Gomont. - J. Phycol. 44: $1572-1585$.

StruneckÝ, O.; Elster, J. \& KomÁrek, J. (2011). Taxonomic revision of the freshwater cyanobacterium "Phormidium" murrayi = Wilmottia murrayi. Fottea 11: 57-71.

Strunecký, O.; Komárek, J.; Johansen, J.; Lukešová, K. \& Elster, J. (2013): Molecular and morphological criteria for revision of the genus Microcoleus (Oscillatoriales, Cyanobacteria). - J. Phycol. 49: 1667-1680.

Silvestro, D. \& MichalaK, I. (2012): raxmlGUI: a graphical front-end for RAxML. - Organisms Divers. Evol. 12: $335-337$. 
StAMATAKIS, A. (2006): RAxML-VI-HPC: maximum likelihood based phylogenetic analyses with thousands of taxa and mixed models. - Bioinformatics 22: 2688-2690.

Suda, S.; Watanabe, M.M.; Otsuka, S.; Mahakahant, A.; Yongmanitchai, W.; Nopartnaraporn, N.; LiU, Y. \& DAY, J.G. (2002): Taxonomic revision of water bloomforming species of oscillatorioid cyanobacteria. - J. Syst. Evol. Microbiol. 52: 1577-1595.

Tamura, K.; Peterson, D.; Peterson, N.; Stecher, G.; Nei, M. \& Kumar, S. (2011): MEGA 5: Molecular evolutionary genetics analysis using maximum likelihood, evolutionary distance, and maximum parsimony methods. - Mol. Biol. Evol. 28: 27312739.

Taton, A.; Wilmotte, A.; Smarda, J.; Elster, J. \& KomÁrek, J. (2011): Plectolyngbya hodgsonii: a novel filamentous cyanobacterium from antarctic lakes. Polar Biol. 34: 181-191.

Thu, N.K.; Tanabe, Y.; Yoshida, M.; Matsuura, H. \& Watanabe, M.M. (2012): Aerosakkonema funiforme gen. et sp. nov. (Oscillatoriales), a new gas-vacuolated oscillatorioid cyanobacterium from a mesotrophic reservoir. - Phycologia 51: 672-683.

Turicchia, S.; Ventura, S.; Komárková, J. \& Komárek, J. (2008): Taxonomic evaluation of cyanobacterial microflora from alkaline marshes of northern Belize. 2. Diversity of oscillatorialean genera. - Nova Hedwigia 89: 165-200.

Vincent, W.F. (2009): Cyanobacteria. - In Likens, G.E. (ed.): Encyclopedia of Inland Waters, Vol. 1. - pp. 226232, Elsevier, Oxford.

Whitton, B.A. \& PotTs, M. (2000): Ecology of cyanobacteria: Their diversity in time and space. - 669 pp., Kluwer Academic Publishers, Dordrecht, Boston.

Zammit, G.; Billi, D. \& Albertano, P. (2012): The subaerophytic cyanobacterium Oculatella subterranea (Oscillatoriales, Cyanophyceae) gen. et sp. nov.: a cytomorphological and molecular description. - Eur. J. Phycol. 47: 341-354.

ZuKER, M. (2003): Mfold web server for nucleic acid folding and hybridization prediction. - Nucl. Acids Res. 31: 3406-3415.

(C) Czech Phycological Society (2014)

Received February 3, 2014

Accepted February 25, 2014 